\title{
PENGARUH PENDIDIKAN KESEHATAN TERHADAP PENINGKATAN PENGETAHUAN REMAJA TENTANG PENYAKIT INFEKSI MENULAR SEKSUAL (HIV, HEPATITIS DAN SIFILIS) DI LINGKUNGAN POLITEKNIK HARAPAN BERSAMA
}

\author{
Nilatul Izah ${ }^{1}$, Juhrotun Nisa ${ }^{2}$, Evi Zulfiana ${ }^{3}$ \\ Email: izzah_naila@yahoo.co.id \\ Prodi D III Kebidanan Politeknik Harapan Bersama \\ Jl. Mataram No.9 Pesurungan Lor Margadana Kota Tegal \\ Telp/Fax (0283) 352000
}

\begin{abstract}
Abstrak
Perkembangan permasalahan Human Immunodeficiency Virus (HIV) dan Acquired Immune Deficiency Syndrome (AIDS) semakin lama semakin mengkhawatirkan baik dari sisi kuantitatif maupun kualitatif. Infeksi HIV tertinggi terjadi pada usia produktif yaitu pada umur 25-49 tahun sebesar 71,8\%. Usia remaja merupakan usia yang paling rentan terinfeksi HIV/AIDs dan Penyakit Menular Seksual (PMS) lainnya. Data Dinas Kesehatan Kota Tegal menyebutkan jumlah penderita HIV/AIDS sebanyak 230 dengan rincian 111 menderita HIV, 119 AIDS, dan 44 meninggal dunia. Banyaknya kasus HIV/AIDS yang terjadi di Indonesia terutama pada usia produktif, sebagian besar disebabkan karena rendahnya pengetahuan tentang HIV/AIDS pada kelompok remaja.

Penelitian ini bertujuan untuk mengetahui Pengaruh Pendidikan Kesehatan terhadap Peningkatan Pengetahuan Remaja tentang Penyakit Infeksi Menular Seksual (HIV, Hepatitis dan Sifilis) dilingkungan Politeknik Harapan Bersama". Penelitian ini merupakan penelitian kuantitatif yang menggunakan rancangan pre eksperimen dengan teknik one group pretest posttest design. Subjek penelitian sebanyak 60 mahasiswa. Analisa data menggunakan uji wilcoxon. Hasil peneltian menunjukkan nilai $\mathrm{P}<0,05$ yang artinya pendidikan kesehan memberikan pengaruh terhadap Peningkatan Pengetahuan Remaja tentang Penyakit Infeksi Menular Seksual (HIV, Hepatitis dan Sifilis) dilingkungan Politeknik Harapan Bersama. Hal ini menunjukkan bahwa pendidikan kesehatan akan meningkatkan pengetahuan, sehingga dapat merubah sikap kearah yang lebih baik.
\end{abstract}

Kata kunci: Pengetahuan, HIV-AIDS, Remaja

\section{Pendahuluan}

Perkembangan permasalahan Human Immunodeficiency Virus (HIV) dan Acquired Immune Deficiency Syndrome (AIDS) semakin lama semakin mengkhawatirkan baik dari sisi kuantitatif maupun kualitatif. Walaupun secara geografi, yang semula diharapkan dapat menghambat perkembangan jumlah Orang Dengan HIV dan AIDS (ODHA) di dunia namun pada kenyataannya dalam kurun waktu 20 tahun terakhir jumlahnya telah mencapai lebih dari 60 juta orang dan 20 juta diantaranya telah meninggal. Tidak mengherankan bila permasalahan $H I V$ dan AIDS telah menjadi epidemi di hampir 190 negara. ${ }^{1}$

Berdasarkan data yang diperoleh dari World Health Organization menyebutkan bahwa pada tahun 2013 sebanyak 1,5 juta orang meninggal karena AIDS termasuk 190.000 diantaranya adalah anak-anak yang berusia $<15$ tahun dan 1,3 juta terjadi pada orang dewasa. ${ }^{2}$

Data dari Kementerian Kesehatan Republik Indonesia tahun 2014, jumlah kasus HIV di Indonesia tahun 2014 sebanyak 22.869 kasus dan kasus AIDS sebanyak 1.876 kasus. Infeksi HIV tertinggi terjadi pada usia produktif yaitu pada umur 25-49 tahun sebesar 71,8\%, diikuti umur 20-24 tahun sebesar 15,7\%. Pada tahun 2014, jumlah kasus AIDS pada laki-laki sebesar $58 \%$ dan perempuan sebesar $42 \%$. Penularannya HIV terjadi melalui heteroseksual sebanyak $39 \% .^{3}$

Usia remaja merupakan usia yang paling rentan terinfeksi HIV/AIDs dan Penyakit Menular Seksual (PMS) lainnya. Bahkan, dalam jangka waktu tertentu, ketika perempuan remaja menjadi ibu hamil, maka kehamilannya dapat mengancam kelangsungan hidup janin/ bayinya. Informasi mengenai masalah 
kesehatan reproduksi, selain penting diketahui oleh para pemberi pelayanan kesehatan, pembuat keputusan, juga penting untuk para pendidikan dan penyelenggara program bagi remaja, agar dapat membantu menurunkan masalah kesehatan reproduksi remaja.

Penyakit menular seksual merupakan suatu penyakit yang mengganggu kesehatan reproduksi yang muncul akibat dari prilaku seksual yang tidak aman. Penyakit Menular Seksual (PMS) merupakan penyakit anak muda atau remaja, karena remaja atau anak muda adalah kelompok terbanyak yang menderita penyakit menular seksual (PMS) dibandingkan kelompok umur yang lain. ${ }^{4}$

Data dari Komisi Penanggulangan AIDS Nasional, faktor resiko terbesar kasus AIDS adalah IDU (Injecting Drug User) sebesar 49,86\%, 41,86\% heteroseksual, 3,90\% homoseksual, $2,59 \%$ transmisi perinatal, $1,70 \%$ dari transfusi darah dan 2,59\% tidak diketahui.

Data Dinas Kesehatan Kota Tegal menyebutkan jumlah penderita HIV/AIDS sebanyak 230 dengan rincian 111 menderita HIV, 119 AIDS, dan 44 meninggal dunia. 61,1 persen dari total jumlah penderita HIV/AIDS yang tercatat masih tergolong usia produktif antara 20 hingga 39 tahun. Data tersebut terbagi menjadi dua, yakni 31,5 persen dengan usia berkisar 20-29 tahun dan 29,6 persen lainnya tergolong usia produktif $30-39 .^{5}$

Banyaknya kasus HIV/AIDS yang terjadi di Indonesia terutama pada usia produktif, sebagian besar disebabkan karena rendahnya pengetahuan tentang HIV/AIDS pada kelompok remaja. Hal ini mungkin disebabkan karena remaja yang tidak mau tahu atau kurang aktif dalam mencari informasi sendiri tentang HIV/AIDS atau informasi lainnya seputar kesehatan reproduksi pada remaja. Salah satu upaya yang dilakukan dalam pencegahan HIV/AIDS yaitu memberikan pengetahuan dan pemahaman yang cukup baik tentang HIV/AIDS pada remaja, untuk dapat meningkatkan pengetahuan remaja, dengan cara memberikan pendidikan kesehatan pada remaja.

$$
\text { Penelitian Handayani (2010), }
$$
menyimpulkan bahwa peningkatan pengetahuan dan sikap siswa setelah diberikan penyuluhan dengan media komik lebih tinggi dibandingkan kelompok yang diberikan penyuluhan dengan media leafleat. $^{6}$ Penelitian Cahyono (2013), menyimpulkan bahwa terjadi peningkatan pengetahuan dan sikap siswa SMA Negeri 2 Sukoharjo sesudah diberikan penyuluhan kesehatan dengan media film.

Hasil wawancara yang dilakukan pada 8 mahasiswa dilingkungan Politeknik Harapan Bersama didapatkan 3 mahasiswa berpengetahuan cukup tentang penyakit infeksi menular seksual dan 5 mahasiswa berpengetahuan kurang tentag penyakit infeksi menular seksual.

Berdasarkan latar belakang tersebut, peneliti tertarik untuk melakukan penelitian tentang "Pengaruh Pendidikan Kesehatan terhadap Peningkatan Pengetahuan Remaja tentang Penyakit Infeksi Menular Seksual (HIV, Hepatitis dan Sifilis) dilingkungan Politeknik Harapan Bersama".

\section{Metode Penelitian}

Penelitian ini merupakan penelitian kuantitatif yang menggunakan rancangan pre eksperimen dengan teknik one group pretest posttest design. Subjek penelitian yaitu mahasiswa Politeknik Harapan Bersama yang terdiri dari 7 Program Studi sebanyak 60 mahasiswa. Pengambilan sampel berdasarkan teknik consecutive sampling. Analisa data menggunakan uji wilcoxon.

\section{Hasil dan Pembahasan}

a. Tabel 1. Karakteristik responden berdasarkan jenis kelamin

\begin{tabular}{lcc}
\hline Jenis Kelamin & $\begin{array}{c}\text { Frekuensi } \\
(\mathrm{n})\end{array}$ & $\begin{array}{c}\text { Prosentase } \\
(\%)\end{array}$ \\
\hline & & \\
Laki-laki & 17 & 28,3 \\
Perempuan & 43 & 71,7 \\
& & \\
\hline \multicolumn{1}{c}{ Jumlah } & 60 & 100,0 \\
\hline
\end{tabular}


b. Tabel 2. Karakteristik responden berdasarkan tempat tinggal

\begin{tabular}{lcc}
\hline \multicolumn{1}{c}{$\begin{array}{c}\text { Tempat } \\
\text { Tinggal }\end{array}$} & $\begin{array}{c}\text { Frekuensi } \\
(\mathrm{n})\end{array}$ & $\begin{array}{c}\text { Prosentase } \\
(\%)\end{array}$ \\
\hline $\begin{array}{l}\text { Tinggal } \\
\text { bersama } \\
\text { orangtua } \\
\text { Kos }\end{array}$ & 44 & 73,3 \\
\hline \multicolumn{1}{c}{ Jumlah } & 16 & 26,7 \\
\hline
\end{tabular}

c. Tabel 3. Tingkat pengetahuan responden sebelum dan setelah mendapatkan pendidikan kesehatan tentang Penyakit Infeksi Menular Seksual (HIV, Hepatitis dan Sifilis) terhadap Peningkatan Pengetahuan Remaja

\begin{tabular}{|c|c|c|c|c|}
\hline & \multicolumn{2}{|c|}{ Sebelum Pendkes } & \multicolumn{2}{|c|}{ Setelah Pendkes } \\
\hline & (n) & $(\%)$ & (n) & $(\%)$ \\
\hline Baik & 18 & 30 & 36 & 60 \\
\hline Cukup & 42 & 70 & 24 & 40 \\
\hline Jumlah & 60 & 100 & 60 & 100 \\
\hline
\end{tabular}

d. Pengaruh pendidikan kesehatan terhadap peningkatan pengetahuan responden tentang Penyakit Infeksi Menular Seksual (HIV, Hepatitis dan Sifilis) terhadap Peningkatan Pengetahuan Remaja

\begin{tabular}{|c|c|c|}
\hline & & $\begin{array}{l}\text { Pengetahuan } \\
\text { setelah pendkes - } \\
\text { Pengetahuan } \\
\text { sebelum pendkes }\end{array}$ \\
\hline $\mathrm{Z}$ & & $-4,243^{\mathrm{a}}$ \\
\hline $\begin{array}{l}\text { Asymp. } \\
\text { tailed) }\end{array}$ & Sig.(2- & ,000 \\
\hline
\end{tabular}

Hasil peneltian dengan uji wilcoxon menunjukkan nilai $\mathrm{P}<0,05$ yang artinya pendidikan kesehan memberikan pengaruh terhadap Peningkatan Pengetahuan Remaja tentang Penyakit Infeksi Menular Seksual (HIV, Hepatitis dan Sifilis) dilingkungan Politeknik Harapan Bersama.

Hal ini menunjukkan bahwa pendidikan kesehatan akan meningkatkan pengetahuan, sehingga dapat merubah sikap kearah yang lebih baik. Sikap adalah tingkatan kedua dalam perilaku. Menurut Bloom yang dikutip oleh Notoatmodjo, seseorang akan merubah sikap jika ia mampu merubah komponen kognitif terlebih dahulu. Informasi yang disampaikan dalam media video drama membe rikan pengaruh pada pengetahuan atau kemampuan kognitif seseorang. Adanya informasi baru mengenai pencegahan HIV/AIDS dapat memberikan landasan kognitif baru bagi terbentuknya sikap pencegahan HIV/AIDS pada responden. ${ }^{4}$

Hasil penelitian tersebut sesuai dengan pendapat yang disampaikan oleh Notoatmodjo yang menyebutkan bahwa penyaluran pendidikan kesehatan akan menciptakan informasi dan menambah pengetahuan ke dalam otak manusia melalui indra penglihatan sebanyak $85 \%$ dan sisanya indra yang lain. ${ }^{4}$ Hasil penelitian inipun sejalan dengan penelitian yang dilakukan oleh, yang menyimpulkan bahwa terjadi peningkatan pengetahuan dan sikap siswa SMA Negeri 2 Sukoharjo sesudah diberikan penyuluhan kesehatan dengan media film. ${ }^{7}$

\section{Kesimpulan}

Hasil penelitian menunjukkan bahwa terdapat penigkatan pengetahuan remaja sebelum dan setelah mendapatkan pendidikan kesehatan tentang penyakit infeksi menular seksual (HIV, Hepatitis dan Sifilis) 


\section{Daftar Pustaka}

[1] Departemen Kesehatan RI, Situasi HIV/AIDS di Indonesia tahun 19872006, 2007.

[2] WHO (2014). HIV-AIDS. Tersedia pada:

http://www.who.int/topics/hiv_aids/ en/ [Diakses tanggal 31 Agustus 2017]

[3] Kemenkes RI, Statistik Kasus HIV/ AIDS di Indonesia, Jakarta: Kemenkes RI, 2014.

[4] Notoatmodjo, S, Pendidikan dan Perilaku kesehatan, Cetakan 2 Jakarta:PT. Rineka Cipta, 2007.
[5] Dinas Kesehatan Kota Tegal, Profil Dinask Kesehatan Kota Tegal, 2017.

[6] Handayani S, Perbandingaan Efektifitas Pemberian Informasi Melalui Buku Cerita Bergambar (Komik) Versi BKKBN dengan Media Leaflet, GASTER. Vol. 7. No. 1. Februari 2010.

[7] Cahyono MD, Pengaruh Penyuluhan Kesehatan Terhadap Pengetahuan dan Sikap Siswa SMA 2 Sukoharjo Tahun 2013, [Skripsi Ilmiah], Surakarta: Fakultas Ilmu Kesehatan UMS, 2013. 